\title{
Knowledge and Attitude of Students of Post-secondary Institutions in Kano, Northern Nigeria Towards the Causes and Prevention of Blindness
}

\author{
S Abubakar, ${ }^{1}$ FW ACP, MSc (London), DLSHTM, A Jibo, ${ }^{2}$ MBBS, U Jibo, ${ }^{3}$ MBBS \\ ${ }^{1}$ Department of Community Medicine, Bayero University Kano/Aminu Kano Teaching Hospital, Kano State, Nigeria \\ ${ }^{2}$ Department of Community Medicine, Aminu Kano Teaching Hospital, Kano State, Nigeria \\ ${ }^{3}$ Faculty of Medicine, Bayero University Kano, Kano State, Nigeria
}

\section{ABSTRACT}

Objective: Blindness is a disabling condition of public health importance in Nigeria. This study assesses the attitude and knowledge of secondary school students, who are mostly adolescents, towards the causes of blindness and its prevention in Kano, Northern Nigeria. The findings of this study will provide important eye health data for this important subgroup of the population as well as identify the gaps in adolescents' knowledge about eye health which can then be modified or targeted through health education.

Method: This cross sectional descriptive study used a multistage sampling method to select 220 secondary school students from 1 girls only secondary school and 1 boys only secondary school located in Tarauni LGA of Kano State in a ratio of 1:1.

Results: The mean age of the respondents was 15.5 years with a standard deviation of 2.5 years, and a male: female ratio of $1: 1$. The level of poor knowledge and attitude about the causes of blindness and its prevention was $62.3 \%$ and $58.2 \%$ respectively.

Conclusion: This study showed that awareness and knowledge of causes of blindness and its prevention were poor among secondary school students. Attitude towards prevention of blindness and perception of respondents regarding the importance of preventing blindness were similarly poor. There is an urgent need to incorporate eye health promotion into secondary school curricula.

Key words: blindness, disability, adolescents, secondary school students, eye health promotion

\section{INTRODUCTION}

Blindness and low vision are major causes of disability and its attendant socioeconomic problems in the society. They affect individuals, families, and the society at large. The negative effects of blindness and low vision are more marked in developing countries due to poor utilization of medical care, as well as poor and inefficient medical and rehabilitative services and shortage of personnel. ${ }^{1}$ The
World Health Organization (WHO) estimates that the number of people with visual impairment worldwide in 2002 was in excess of 161 million, of which about 37 million were blind. ${ }^{2}$ The World Health Organization defines blindness as presenting visual acuity of less than $3 / 60$ or inability to count fingers at a distance of 3 metres in the better eye, using available means of correction. ${ }^{3}$ The global target is to ultimately reduce blindness prevalence to less than $0.5 \%$ in all countries, or less than $1.0 \%$ in any community. ${ }^{4}$ According to 1990 WHO estimates, the world prevalence of blindness was $0.7 \%$, ranging from $0.3 \%$ in the established market economies to $1.4 \%$ in sub-Saharan Africa. ${ }^{5}$

The main causes of blindness are avoidable and vary from place to place, from region to region, and from country to country. However, the prevalence of avoidable blindness is high in most parts of the world, especially in the developing world, and cataract is the leading cause. ${ }^{6,7}$ Trachoma is particularly a disease of children and women who live in poor areas of the world with inadequate water supply and poor environmental sanitation. Onchocerciasis occurs close to rivers in West and Central Africa with similar foci of disease in Ethiopia and East Africa. Vitamin A deficiency is often associated with measles in Africa, with most of the prevalence occurring in children aged 1-3 years, living where there is famine. Eye disease and blindness due to human immunodeficiency virus/acquired immuno-deficiency syndrome is increasing, particularly in southern and eastern Africa. The consequence is that despite the availability of relatively inexpensive and very effective interventions known to medical science, over 80 percent of all blindness that occurs in Africa is either preventable or treatable. ${ }^{6}$

This study intends to determine the attitude, perception and knowledge of causes of blindness amongst students, against the backdrop of high rates of blindness in sub-Saharan Africa. The students in this study were adolescents who are in a good position to influence the eye-health- seeking behaviour of their peers or siblings. In addition, this study will provide important eye health data for this important subgroup of the population. The information will also go a long way to support the global initiative for the elimination of blindness, Vision 2020 - "the Right to Sight". This is a collaborative effort between the World Health Organization and the International Agency for the Prevention of Blindness. The partnership was launched in February 1999 to strengthen ongoing

*Correspondence: S. Abubakar, Department of Community Medicine, Aminu Kano Teaching Hospital (AKTH), P.M.B. 3452, Kano State, Nigeria • abubakarsanusi@yahoo.com 
prevention of blindness activities through national capacity-building. It focuses on three components: disease control, human resource and infrastructure, and technology development. ${ }^{8}$

\section{METHODOLOGY}

A descriptive cross sectional study design was used to examine a calculated random sample ${ }^{9}$ of two hundred and twenty day secondary school students attending the selected secondary schools, using a multistage sampling technique between January-February 2008, after obtaining permission and ethical clearance from the schools management board, the school principals and their class teachers. Informed consent was also obtained from the selected students before the questionnaire was administered to them. The sampling involved stratifying all the secondary schools located in the LGA into six male only and five female only schools. Thereafter one male only school, i.e. Government Day Secondary School, Tarauni, and one female only school, i.e. Fatima Muhammad Girls Secondary School, Gyadi-Gyadi, Tarauni were selected at random. The next stage involved selecting one set or class level from each of the selected schools. The final stage was conducted by selecting respondents at random from a list of all the students in all the classes in the already selected set and the interviewer then administered the questionnaire to the respondents after obtaining their informed consent.

The collected data was analysed using Epi-info software version 3.3.2 and was presented in the form of tables. Quantitative data were expressed as mean and standard deviation, and qualitative data were expressed as percentages. P-value of less than 0.05 was deemed significant. The scores for grading of knowledge of causes of blindness were a maximum of 30 and a minimum of zero. A score of 22 and above was regarded as good knowledge, while scores of 14 - 21 were regarded as fair knowledge, and a score of less than 14 was regarded as poor knowledge. The scores for grading of attitude towards blindness was a maximum of 9 and a minimum of zero. Scores of 7 - 9 were regarded as good while 5-6 were graded as fair and less than 5 was regarded as poor.

\section{RESULTS}

\section{Socio-demographic Characteristics of Respondents}

The distribution of respondents by age, religion, marital status, ethnic group and sources of information is shown in table 1 . About half of the respondents (50.3\%) fell between the age group of 13-15 years, with a male to female ratio of $1: 1$. Most of the respondents

Knowledge About Causes of Blindness, Attitude Towards and Perceived Importance of Blindness Prevention

Only $20.0 \%$ of the respondents had good level of knowledge of causes of blindness and its prevention, with $58.2 \%$ of the respondents having poor attitude towards blindness prevention while only $15.9 \%$ of the respondent felt blindness prevention was very important (table 2).
(97.3\%) were Muslims; only $2.7 \%$ were Christians. The majority of the respondents (97.7\%) were single and only $1.4 \%$ were married. A larger portion of the respondents (84.1\%) were Hausa. The commonest source of information about the causes of blindness was from blind relatives or blind people that they knew (49.6\% of respondents).

Table 1. Socio-demographic characteristics of respondents

\begin{tabular}{|c|c|c|c|}
\hline $\begin{array}{l}\text { Socio- } \\
\text { demographic } \\
\text { Variable }\end{array}$ & $\begin{array}{c}\text { Socio-demographic } \\
\text { Parameter }\end{array}$ & Frequency & $\%$ \\
\hline \multirow{6}{*}{$\begin{array}{l}\text { Age Group } \\
\text { (years) }\end{array}$} & $10-12$ & 16 & 7.3 \\
\hline & $13-15$ & 111 & 50.5 \\
\hline & $16-18$ & 66 & 30.0 \\
\hline & $19-21$ & 24 & 10.9 \\
\hline & $22-24$ & 3 & 1.4 \\
\hline & Total & 220 & 100.0 \\
\hline \multirow[t]{2}{*}{ Sex } & Male & 110 & 50 \\
\hline & Female & 110 & 50 \\
\hline \multirow[t]{6}{*}{ Ethnicity } & Fulani & 20 & 9.1 \\
\hline & Hausa & 185 & 84.1 \\
\hline & Igbo & 6 & 2.7 \\
\hline & Kanuri & 7 & 3.2 \\
\hline & Yoruba & 2 & 0.9 \\
\hline & Total & 220 & 100 \\
\hline \multirow[t]{4}{*}{$\begin{array}{l}\text { Sources of } \\
\text { information }\end{array}$} & $\begin{array}{l}\text { From blind } \\
\text { relatives/blind people }\end{array}$ & 109 & 49.6 \\
\hline & $\begin{array}{l}\text { Health education by } \\
\text { school teacher }\end{array}$ & 48 & 21.8 \\
\hline & Through the mass media & 63 & 28.6 \\
\hline & Total & 220 & 100 \\
\hline \multirow[t]{3}{*}{ Religion } & Islam & 214 & 97.3 \\
\hline & Christianity & 6 & 2.7 \\
\hline & Total & & \\
\hline \multirow[t]{4}{*}{ Marital status } & Married & 3 & 1.4 \\
\hline & Single & 215 & 97.7 \\
\hline & Widowed/Separated & 2 & 0.9 \\
\hline & Total & 220 & 100.0 \\
\hline
\end{tabular}

Table 2. Level of knowledge about the causes of blindness, attitude towards, and perceived importance of blindness prevention

\begin{tabular}{|c|c|c|c|}
\hline Variables & Parameters & Frequency & $\%$ \\
\hline $\begin{array}{l}\text { Awareness about } \\
\text { causes of blindness }\end{array}$ & Aware & 99 & 45 \\
\hline Level of knowledge & Good knowledge & 44 & 20 \\
\hline
\end{tabular}




\begin{tabular}{llcc}
\hline & Fair knowledge & 39 & 17.7 \\
& Poor knowledge & 137 & 62.3 \\
\hline Perceptions about the & Very important & 35 & 15.9 \\
importance of & Fairly important & 31 & 14.1 \\
blindness prevention & Not important & 60 & 27.3 \\
& No response & 94 & 42.7 \\
\hline Attitude towards & Good & 37 & 16.8 \\
causes of blindness & Fair & 55 & 25 \\
and its prevention & Poor & 128 & 58.2 \\
\hline Frequently stated & Use of drugs & 30 & 13.6 \\
methods of preventing & Health education on & 60 & 27.3 \\
blindness & eye conditions & & \\
& Improve personal & 22 & 10.0 \\
& hygiene & & \\
& Periodic eye & 100 & 45.5 \\
& examinations & 8 & 3.6 \\
\hline & Others & & \\
\hline
\end{tabular}

Social and Demographic Factors Influencing Respondents' Knowledge of Causes of Blindness and its Prevention

Table 3 shows the statistically significant association between knowledge of causes of blindness with age $\left(\chi^{2}=6.36, \mathrm{df}=1, \mathrm{p}<\right.$ $0.005)$ and $\operatorname{sex}\left(\chi^{2}=4.2, \mathrm{df}=1, \mathrm{p}<0.05\right)$.

Table 3. Social and demographic factors influencing respondents' knowledge of causes of blindness and its prevention

\begin{tabular}{llllll}
\hline $\begin{array}{l}\text { Characteristics } \\
(\mathbf{n}=\mathbf{2 0 0})\end{array}$ & \multicolumn{2}{c}{ Knowledge } & $\begin{array}{l}\text { Chi-squared } \\
\left(\chi^{2}\right) \\
\text { statistic }\end{array}$ & $\begin{array}{l}\text { P }- \\
\text { value } \\
\text { \& Fair }\end{array}$ & $\begin{array}{l}\text { Signifi- } \\
\text { cance }\end{array}$ \\
\hline Age & & & $5.4^{* *}$ & $\mathrm{P}<.05$ & significant \\
$10-18$ years & 79 & 114 & & & \\
$19-24$ years & 18 & 9 & & $\mathrm{P}<.05$ & significant \\
Sex & & & 4.2 & \\
Male & 39 & 71 & & & \\
Female & 54 & 56 & & & \\
\hline \hline
\end{tabular}

$* *=$ Yates corrected value

\section{DISCUSSION}

The study was conducted amongst 220 randomly selected students form one girls only and one boys only secondary school. The mean age of the respondents was 15.5 years with a standard deviation of 2.5 years. Up to $87.8 \%$ of the students fell within the age group of 10-18 years and this is similar to the findings of the study conducted in north central Nigeria, where more than half of the respondents were less than 16 years. ${ }^{10}$ Most of the respondents were Hausa and Fulani, this is not unexpected because the study was conducted in Kano metropolis where the residents are predominantly Hausa and Fulani. The level of knowledge about the causes of blindness was generally poor, which is keeping with other related studies; $;{ }^{112}$ more than half of the respondents had poor level of knowledge about the causes of blindness which may be explained by the fact that teaching about the medical causes of blindness is not included in the curriculum of secondary school students and there are very few or no population-oriented public enlightenment programmes on the causes of blindness. Most of the respondents had blind relatives or blind people as their commonest source of information on blindness, which is a pointer to the unavailability of health services or mass media based information about blindness and its prevention, this contrasts with the findings of another study conducted among health workers in South-East Nigeria, ${ }^{13}$ which revealed that the mass media was their commonest source of information on causes of blindness. However, the respondents in the latter study were older and more educated than the respondents in this study. The poor level of knowledge obtained in this study was however similar to the results obtained from studies conducted in India and New Zealand. ${ }^{14,15}$ The latter studies are population based studies that was used as proxies for comparison in view of the dearth of similar published studies. There was a statistically significant association between knowledge of causes of blindness with age. This may be due to the fact that older respondents are more likely than younger ones to know more about the causes of blindness because they are usually in more senior classes with better chances of having been taught the various causes of blindness. There was also a statistically significant association between knowledge of causes of blindness with the sex of the respondents and this is consistent with the propensity for women to seek out preventive health care compared with men. ${ }^{9}$ The attitude of the respondents towards the prevention of blindness was also quite poor, more than half of the respondents had poor attitude towards blindness and its prevention, which is not unexpected in view of the poor knowledge of respondents regarding the causes of blindness. However, it was encouraging that $45.5 \%$ of the respondents thought that blindness can be eradicated through periodic eye examinations while only $27.3 \%$ of the respondents felt that blindness prevention was unimportant. Negative attitude towards blindness is not uncommon, as shown in another study ${ }^{16}$ where $80 \%$ of the respondents said that they would not marry a blind person, and only $14 \%$ of the respondents were willing to employ a blind person.

This study showed that awareness and knowledge of causes of blindness and its prevention was poor among adolescent students. Attitude towards prevention of blindness and perception of respondents regarding the importance of preventing blindness was also similarly poor. Most of the respondents obtained information about causes of blindness from relatives that are blind or blind people that they knew, and the most commonly stated method of preventing blindness was periodic eye examination. Females and older respondents generally had better knowledge of causes of blindness and this was statistically significant.

These findings indicate the low importance attached to eye health promotion, especially among adolescents. It also signifies the need to incorporate eye health promotion into the curricula of secondary schools if the targets for the eradication of blindness are to be achieved by the IAPB, WHO and its partners.

\section{ACKNOWLEDGEMENTS}

We acknowledge and appreciate the co-operation of the staff and students of the secondary schools in which this study was conducted.

\section{REFERENCES}

1. Robin AL, Nirmalan PK, Krishnadas R, Ramakrishnan R, Joanne 
Katz J, Tielsch J et al.The Utilization Of Eye Care Services By Persons With Glaucoma In Rural South India. Trans Am Ophthalmol Soc 2004 December; 102: 47-56.

2. Resnikoff S, Pascolini D, Etya'ale D, Kocur I, Pararajasegaram $\mathrm{R}$, et al. Global data on visual impairment in the year 2002. Bull World Health Organ 2004; 82: 844-851.

3. World Health Organization. international Statistical Classification of Diseases and Related Health Problems: Icd-10. Tenth Revision, Volume 1. Geneva: World Health Organization; 2004. Diseases of the eye and adnexa; pp. 426-428.

4. World Health Organization. Strategies for the prevention of blindness in national programmes-a primary health care approach. Geneva: World Health Organization; 1997. Available: http://whqlibdoc.who.int/publications/9241544929. pdf.

5. Thylefors B, Negrel AD, Pararajasegaram R et al. Global data on blindness. Bull World Health Organ 1995; 73:115-21.

6. Adetokunbo O, Lucas AO, Gilles H. A Short Textbook of Public Health Medicine for the Tropics. $4^{\text {th }}$ Edition. Oxford University Pres Inc. 2003; 4:65-69.

7. Abdu L, Foster A. Assessment of resource utilization for delivery of eye surgical services. Nig J of Basic and Clinical Sciences $2005 ; 1-2$.

8. WHO Regional Committee for Africa. Accelerating the elimination of avoidable blindness. A strategy for the WHO African Region. Brazzaville, Republic of Congo. 2007; 32:1234-1239.

9. Saw SM, Gazzard G, Friedman D, Foster PJ et al. Awareness of glaucoma, and health beliefs of patients suffering primary acute angle closure. Br J Ophthalmol 2003; 87(4): 446-449.

10. Odugbo P. Causes of blindness in blind schools in Plateau, Bauchi and Kaduna states, Nigeria. MSc Dissertation, ICEH, LSH\&TM; 2005: 1-3.

11. Ntim-Amponsah CT, Winfried AMK, Ofosu-Amaah S. Awareness and knowledge of glaucoma and other diseases associated with blindness in a Ghanaian community. Nigerian Journal of Ophthalmology 2004; 12 (2): 50 - 54.

12. Nwosu SNN. Beliefs and attitude to eye diseases and blindness in rural Anambra State, Nigeria. Nigerian Journal of Ophthalmology. August 2002; 1 (1): $16-20$.

13. Adegbehingbe BO, Bisiriyu LA. Knowledge, attitudes, and self care practices associated with glaucoma among hospital workers in Ile-Ife, Osun State, Nigeria. Tanzania Journal of Health Research 2008; 10 (4): 240-245.

14. Giridhar P, Dandona R, Prasad MN, Kovai V, Dandona L. Fear of blindness and perceptions about blind people. The Andhra Pradesh eye disease study. Indian J Ophthalmol 2002; 50:239.

15. Attebo K, Mitchell P, Cumming R, Smith W. Knowledge and beliefs about common eye diseases. Aust N Z J Ophthalmol 1997; 25(4): 283- 7 .

16. Alemayehu W, Tekle-Haimanot R, Forsgren L, Ekstedt. Perceptions of blindness. World Health Forum 1996; 17:379-81. 